\section{Isolation and Structure Elucidation of I-851, an Antagonist of Chloramphenicol}

\author{
Yoshitaka Imagawa, Shoji ShIma, \\ Akira Hirota and Heiichi SAKaI \\ Department of Agricultural Chemistry, \\ College of Agriculture, University of Osaka \\ Prefecture, Sakai, Osaka, Japan
}

Received October 20, 1977

In screening for antagonists of the antibiotics from microbial origins, a culture of Streptomyces sp. No. 851 isolated from soil was found to produce an antagonist of chloramphenicol. The substance tentatively named I-851 markedly diminishes the antibiotic action of chloramphenicol against Escherichia coli. The antagonist of antibiotic agent showed several interesting biological activities to counteract the toxicity of the antibiotic agent. ${ }^{1)}$ In this paper we wish to report the isolation and structure elucidation of the substance.

The strain producing I-851 grew well on various media, and its aerial mycelium was straight and the size of spore was $c a .0 .75 \times$ $c a .1 .2 \mu$. The spore had smooth surface. The strain contained LL-diaminopimelic acid in the cell wall. As the carbon source, Dglucose, D-mannitol, L-arabinose, D-xylose, Lrhamnose, D-fructose, raffinose, inositol, salicin and sucrose were found to be well utilized, while sorbitol, sorbose and erythritol were not utilized. The strain was found to belong to the species, Streptomyces fulvoviolaceus, according to the guide in Bergey's Manual. ${ }^{2}$ )

Production of I-851 was carried out in a 20-liter jar fermentor containg 14 liters of a fermentation medium composed of $2 \%$ glycerin, $0.5 \%\left(\mathrm{NH}_{4}\right)_{2} \mathrm{SO}_{4}, 0.4 \%$ soybean meal, $0.1 \%$ yeast extract, $0.2 \% \mathrm{NaCl}, 0.14 \% \mathrm{KH}_{2} \mathrm{PO}_{4}$ $0.36 \% \mathrm{Na}_{2} \mathrm{HPO}_{4} \cdot 12 \mathrm{H}_{2} \mathrm{O}$ (adjusted to $\mathrm{pH} 7.4$ ). Fermentation was conducted with agitation $(300 \mathrm{rpm})$ and aeration (8 liters/min) for $30 \mathrm{hr}$ at $30^{\circ} \mathrm{C}$. The cultured broth was adjusted to $\mathrm{pH} 6$ with $\mathrm{NaOH}$. The active substance was extracted with ethyl acetate, adsorbed on a column of silica gel and eluted with benzeneethyl acetate (95:5). I-851 was obtained as yellow crystals, $\mathrm{mp} 153 \sim 155^{\circ} \mathrm{C}$ (dec.).

The molecular formula of I-851 was determined to be $\mathrm{C}_{7} \mathrm{H}_{5} \mathrm{NO}_{5}$ by high resolution mass spectrometry $\left(\mathrm{M}^{+}\right.$, m/e: 183.0146: calcd. for $\left.\mathrm{C}_{7} \mathrm{H}_{5} \mathrm{NO}_{5}, 183.0167\right) . \quad \mathrm{IR} \nu_{\max }^{\mathrm{KBr}} \mathrm{cm}^{-1}: 3350,3250$, $2730,1700,1590,1500,1440,1370,1250,1050$, $990,880,750,570$. UV $\lambda_{\max }^{\mathrm{MeOH}} \mathrm{nm}(\varepsilon): 244$ (9150), 292 (15200), 349 (660). This substance was positive to 2,4-dinitrophenyl hydrazine. The IR spectrum of I-851 shows absorption bands at 3350 and $3250 \mathrm{~cm}^{-1}$ due to the amino group and $1700 \mathrm{~cm}^{-1}$ due to an $\alpha, \beta$-unsaturated carbonyl group. The NMR spectrum is shown in Fig. 1. Signals at $\delta 4.02$ and 4.22 ppm (each $1 \mathrm{H}, \mathrm{d}, J=4 \mathrm{~Hz}$ ) were assigned as two epoxy protons. The two epoxy protons were adjacent respectively to the carbonyl group as judged from the chemical shift at the lower field. Signals at $\delta 13.2,10.0$ and 8.6 ppm disappered on treatment with $\mathrm{D}_{2} \mathrm{O}$. A

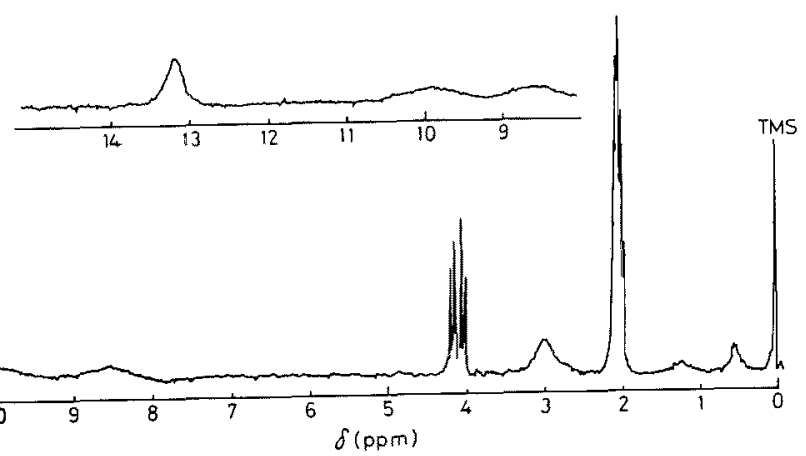

FIG. 1. ${ }^{1} \mathrm{H}-\mathrm{NMR}$ Spectrum of $1-851\left(100 \mathrm{MHz}\right.$, in Acetone $\left.\mathrm{d}_{\theta}\right)$. 
signal at $\delta 13.2$ was assigned as the hydroxy proton of the carboxyl group, and amino protons were observed nonequivalently at $\delta 10.0$ and $8.6 \mathrm{ppm}$, respectively. In the CMR spectrum of I-851, signals at $\delta 187.4$ (s) and 192.8 (s) $\mathrm{ppm}$ indicated the presence of two carbonyl carbons. The carboxyl carbon was observed at $\delta 168.7$ (s) ppm. The epoxy carbons were observed at $\delta 53.6(\mathrm{~d}, J=54.2 \mathrm{~Hz})$ and $55.4(\mathrm{~d}, J=52.7 \mathrm{~Hz}) \mathrm{ppm}$, respectively. Moreover, two olefin carbons were observed at $\delta 96.4$ (s) and $155(\mathrm{~s}) \mathrm{ppm}$. The $\mathrm{p} K a$ values obtained from the titration curve of $\mathrm{I}-851$ were 6.1 and 9.7. These values suggested the presence of both carboxyl and amino groups. The UV absorption of I-851 at 244 and $349 \mathrm{~nm}$ indicated that it resembled phyllostine. ${ }^{3)}$ However, the UV absorption of I-851 at $292 \mathrm{~nm}$ was different from that of phyllostine. This absorption indicated the presence of an $\alpha, \beta$ unsaturated carboxyl group. All the abovementioned data suggested that the structure of I-851 is 2-amino-3-carboxy-1,4-benzoquinone 5,6 -epoxide (I). It is a new nitrogen-containing derivative of cyclohexene epoxide, e.g. terreic acid, ${ }^{4}$ epoxydon ${ }^{51}$ and phyllostine.

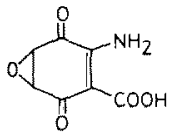

I

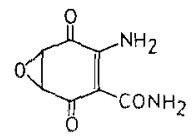

II
The structure of I-851 (I) was similar to that of antibiotic G7063-2 (II), ${ }^{6)}$ recently isolated as a nitrogen-containing derivative of cyclohexene epoxide. Antibiotic G7063-2 was moderately active against bacteria, whereas I-851 was an antagonist of chloramphenicol. The biological activities of I-851 as antagonist of chloramphenicol are now under investigation. ${ }^{\text {) }}$

Acknowledgements. The authors wish to express their thanks to Dr. A. Isogai, Department of Agricultural Chemistry, The University of Tokyo, for the measurement of the NMR spectra and helpful discussions. The authors are also indebted to Fujisawa Pharmaceutical Co., Ltd., for electron microscopic measurement and to Takeda Chemical Industries, Co., Ltd., for the measurement of high resolution mass spectrum.

\section{REFERENCES}

1) H. Yonehara, H. Seto, A. Shimazu, S. Aizawa, T. Hidaka, K. Kakinuma and N. Ötake, Agric. Biol. Chem., 37, 2771 (1973).

2) T. G. Pridham and H. D. Tresner, Streptomycetaceae, in Bergey's Manual of Determinative Bacteriology (8 th Edition), The Williams and Wilkins Co., 1974, pp. 747 845 .

3) S. Sakamura, J. Ito and R. Sakai, Agric. Biol. Chem., 34, 153 (1970).

4) J. Sheehan, W. Lawson and R. Graul, $J . A m$. Chem. Soc., 80, 5536 (1958).

5) A. Closse, R. Mauli and H. P. Sigg, Helv. Chim. Acta, 49, 204 (1966).

6) M. Noble and D. Noble, J. Antibiot., 30, 455 (1977).

7) Petri plates were prepared with bouillon medium inoculated with $E$. coli and containing an inhibitory concentration of $10 \mu \mathrm{g} / \mathrm{ml}$ of chloramphenicol. The paper discs containing I-851 at the concentration of $0.625 \sim 5 \mu \mathrm{g} /$ disc were placed on the agar surface. Zones of growth appeared around each disc containing I-851. 